\title{
Pan Bouyoucas, Le mauvais œil
}

\section{Jean-François Plamondon}

\section{(2) OpenEdition}

Journals

Édition électronique

URL : http://journals.openedition.org/studifrancesi/4511

DOI : 10.4000/studifrancesi.4511

ISSN : 2427-5856

\section{Éditeur}

Rosenberg \& Sellier

\section{Édition imprimée}

Date de publication : 1 septembre 2016

Pagination : 383-384

ISSN : 0039-2944

\section{Référence électronique}

Jean-François Plamondon, «Pan Bouyoucas, Le mauvais œil », Studi Francesi [En ligne], 179 (LX | II) |

2016, mis en ligne le 01 septembre 2016, consulté le 18 septembre 2020. URL : http://

journals.openedition.org/studifrancesi/4511 ; DOI : https://doi.org/10.4000/studifrancesi.4511

\section{Ce document a été généré automatiquement le 18 septembre 2020}

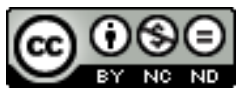

Studi Francesi è distribuita con Licenza Creative Commons Attribuzione - Non commerciale - Non opere derivate 4.0 Internazionale. 


\title{
Pan Bouyoucas, Le mauvais ceil
}

\author{
Jean-François Plamondon
}

\section{RÉFÉRENCE}

PAN BOUYOUCAS, Le mauvais œil, Montréal, Les allusifs, 2015, 140 pp.

1 Originaire de la Grèce et vivant au Québec depuis 1963, Pan Bouyoucas est l'auteur d'une œuvre qui compte une douzaine de romans, quatre pièces de théâtre et deux recueils de nouvelles. S'il fut traducteur et architecte dans ses jeunes années, l'écrivain se consacre depuis la fin des années 1990 à la littérature. Son œuvre se veut discrète quoiqu'elle se fasse tout de même remarquer par des prix, démontrant ainsi que le travail de l'auteur fait doucement son chemin vers une reconnaissance plus institutionnalisée. Ainsi, en 2004, avec Anna Pourquoi, il recevait le Prix Littéraire des collégiens et l'année suivante, L'Homme qui voulait boire la mer était sélectionné par la FNAC comme l'un des meilleurs romans de la rentrée. Certes ces récompenses critiques sont moins prestigieuses que les prix Goncourt, Femina et autre Médicis, mais elles ne légitiment pas moins une œuvre dont la qualité ne fait aucun doute. Avec ce douzième roman, Bouyoucas raconte la vie paisible des habitants d'une île bousculée par l'arrivée d'une étrangère qui, croit-on, porte le mauvais œil. Immigrante et femme d'un homme de l'île qui revient vivre sa retraite dans son pays, Madame Piano devient la responsable de tout ce que son environnement connaît de revers, dont la chute dramatique du tourisme (industrie première de l'île) et la disparition de l'ainée des enfants d'une famille fort influente. C'est toute une galerie d'individus colorés qui anime ce drame fantaisiste et en fait un récit à la fois savoureux et agréable à lire, malgré le côté tragique que vit notamment Madame Piano. En effet, la présence de l'étrangère sur l'île dérange les insulaires et Madame Piano n'est pas sans le savoir. Aussi, les rumeurs se multiplient à son sujet, elle porterait le mauvais œil et malheur à l'île. Malgré une allure inoffensive, ce récit donne à voir le destin de l'étranger qui émigre dans un pays pour qui l'intégration est synonyme d'assimilation. En suivant ce principe, la clé du bonheur dans le nouvel espace de vie de l'immigrant est l'abnégation la plus complète. Se mortifier comme les religieuses cloîtrées, se retirer du monde 
comme les femmes des béguinages, voilà le destin qui attend Madame Piano, elle qui aurait tant aimé apporter un peu d'elle-même au service des insulaires. Avec ce Mauvais œil, Bouyoucas livre un très bon douzième roman qui est de ton dans cette époque de chambardements migratoires et de débats sur la déchéance de nationalité. 